\title{
Online detection of waterborne bioavailable copper by valve daily rhythms in freshwater clam Corbicula fluminea
}

\author{
L. J. Jou • W. Y. Chen • C. M. Liao
}

Received: 21 February 2008 / Accepted: 3 June 2008 / Published online: 8 July 2008

(C) Springer Science + Business Media B.V. 2008

\begin{abstract}
Freshwater clam Corbicula fluminea, a surrogate species in metal toxicity testing, is a promising bioindicator of impairment in aquatic ecosystems. Little is known, however, about the relationship between clam valve daily rhythmic response and metal bioavailability related to a metal biological early warning system (BEWS) design. The purpose of this study was to link biotic ligand model (BLM)-based bioavailability and valve daily rhythm in $C$. fluminea to design a biomonitoring system for online in situ detection of waterborne copper $(\mathrm{Cu})$. We integrated the Hill-based dose-time-response function and the fitted daily rhythm function of valve closure into a constructed programmatic mechanism. The functional presentation of the present dynamic system was completely demonstrated by employing a LabVIEW graphic control program in a personal computer. We used site-specific effect concentration causing $10 \%$ of total valve closure response (EC10) as the detection threshold to implement
\end{abstract}

\section{J. Jou}

Department of Biomechatronic Engineering,

National Ilan University,

Ilan, Taiwan 260, Republic of China

W. Y. Chen · C. M. Liao $(\varangle)$

Department of Bioenvironmental Systems

Engineering, National Taiwan University,

Taipei, Taiwan 10617, Republic of China

e-mail: cmliao@ntu.edu.tw the proposed $C$. fluminea-based $\mathrm{Cu}$ BEWS. Here our results show that the proposed $C$. flumineabased BEWS could be deliberately synthesized to online in situ transmit rapidly the information on waterborne bioavailable $\mathrm{Cu}$ levels under various aquatic environmental conditions through monitoring the valve daily rhythmic changes. We suggested that the developed $C$. fluminea-based dynamic biomonitoring system could assist in developing technically defensible site-specific water quality criteria to promote more efficient uses in water resources for protection of species health in aquatic environments.

Keywords Clam • Corbicula fluminea . Valve daily rhythm • Bioavailability $\cdot$ Copper . Biological early warning system

\section{Introduction}

The behavioral activity of valve acclimated in a laboratory has been used as a measurable biological response exposed to various aquatic environmental conditions (e.g., temperature, $\mathrm{pH}$, humic acid, dissolved organic carbon, and toxicant dose etc.) to quantify the environmental influence or toxicity effect to freshwater bivalves (Doherty et al. 1987; Byrne et al. 1990; Sluyts et al. 1996; Curtis et al. 2000; Kadar et al. 2001; Markich 2003; Ortmann and Grieshaber 2003; Tran et al. 2003; 
Fournier et al. 2004). In addition, using the valveclosure response or rhythmic gaping pattern as an early warning indicator of monitoring water quality can enable us to diagnose the presence of pollution (Borcherding and Volpers 1994).

Applying bivalve closure responses to detect the degree of toxicant have frequently been studied in ecotoxicology as an aquatic contamination biomonitor (Sluyts et al. 1996; Wildridge et al. 1998; Curtis et al. 2000; Kadar et al. 2001; Heinonen et al. 2003; Tran et al. 2003, 2004, 2007). Bivalves are widely distributed filter feeders that have often been used as test organisms and bioindicators of aquatic pollution (Lopez-Barea and Pueyo 1998; Mitchelmore and Chipman 1998; Wilson et al. 1998; Narbonne et al. 1999; Le Pennec and Le Pennec 2001).

The use of freshwater clam Corbicula fluminea as a surrogate species in metal toxicity testing has supported that the $C$. fluminea is a promising bioindicator of impairment in aquatic ecosystems (Dohery and Cherry 1988; Tran et al. 2003, 2004, 2007; Fournier et al. 2004; Jou and Liao 2006; Liao et al. 2007). Cherry and Soucek (2006) have intensively reviewed the practical uses of $C$. fluminea as an in situ monitoring test organism, suggesting the increasing importance of integrating in situ bioassays using field-caged bivalves with traditional measures of ecological integrity.

At present, little is known, however, about the relationship between clam valve daily rhythmic response and metal bioavailability related to a metal biological early warning system (BEWS) design. In such case, the metal-induced biological response can be related either to the free-metal ion concentration in solution usually described by free ion activity model (FIAM), or to the metal bound to sensitive sites at the surface of the organism described by biotic ligand model (BLM) (Paquin et al. 2002; Niyogi and Wood 2004). Our previous studies (Liao et al. 2007) indicated that free ionic form of waterborne $\mathrm{Cu}$ bind specifically to a biotic ligand (i.e., clam gills) and impair normal valve closure behavior. It indicated that a fixed-level of metal accumulation at a biotic ligand is required to elicit specific biological effects. Liao et al. (2007) also demonstrated that the timedependent $\operatorname{EC50}(t)$ and valve closure behavior in response to $\mathrm{Cu}$ at any response time could be well predicted. We therefore suggested that BLM could be improved to describe rigorously the bioavailability of metal causing toxicity to valve closure behavior in $C$. fluminea.

The purpose of this study was to link biotic ligand model (BLM)-based bioavailability and valve daily rhythm in $C$. fluminea to design a biomonitoring system for online in situ detection of waterborne $\mathrm{Cu}$. We employed a LabVIEW graphic control program in a personal computer to simulate and demonstrate the functional presentations of the proposed clam valve-based biomonitoring system.

\section{Materials and methods}

Principle and methodology of system design

In our previous paper (Liao et al. 2007), we have developed a model describing the interaction between bioavailability of free $\mathrm{Cu}^{2+}$-activity and C. fluminea valve daily rhythm based on BLM and Hill-based dose-response model. We refereed to the model as the Cu-BLM-Corbicula model. Table 1 (Eqs. (T1)-(T4)) gives the essential mathematical expressions used to describe the $\mathrm{Cu}$ BLM-Corbicula model.

The two-step approach is used to process the $\mathrm{Cu}-\mathrm{BLM}$-Corbicula model into the C. flumineabased dynamic metal detection mechanism. In the first step, we have to observe the valve daily rhythm dynamic fashion in response to $\mathrm{Cu}$ to indirectly obtain a BLM-based concentrationtime-response profile. In the second step, we need to estimate the waterborne free $\mathrm{Cu}^{2+}$-activity $\left\{\mathrm{Cu}^{2+}\right\}$ by using the major physiological parameters in $C$. fluminea and thus that a real waterborne $\mathrm{Cu}$ ion concentration $\left[\mathrm{Cu}^{2+}\right]$ can then be evaluated depending on the site-specific water quality conditions.

In the simulated interface of a visual window, the measured waterborne metal ionic concentration (e.g., $\left[\mathrm{Ca}^{2+}\right],\left[\mathrm{Mg}^{2+}\right],\left[\mathrm{Na}^{+}\right]$and $\left[\mathrm{Cu}^{2+}\right]$ etc.), temperature, $\mathrm{pH}$ and the other observed water quality data were logged in first. The principles of hydrochemistry were employed to calculate the metal ionic strength and activity factors to obtain the site-specific metallic ionic activity. 
Table 1 The mathematical expressions for describing Cu-BLM-Corbicula model, clam daily closing rhythm exposed to uncontaminated environment and waterborne $\mathrm{Cu}$ (see text for the meanings of symbols)

Mathematical expressions
Cu-BLM-Corbicula model ${ }^{\mathrm{a}}$
$R\left(t_{R}, \mathrm{Cu} u^{2+}\right)=\frac{R_{\max } \times\left\{\mathrm{Cu}^{2+}\right\}^{n\left(t_{R}\right)}}{\left[\mathrm{EC} 50_{\mathrm{CuBL}}\left(t_{R}\right)\right]^{n\left(t_{R}\right)}+\left\{\mathrm{Cu}^{2+}\right\}^{n\left(t_{R}\right)}}$
Where
Time-varying BLM-predicted $50 \%$ effective response concentration function
EC50 $0_{\mathrm{CuBL}}\left(t_{R}\right)=\frac{f_{\mathrm{CuBL}}^{50 \%}\left(t_{R}\right)}{1-f_{\mathrm{CuBL}}^{50 \%}\left(t_{R}\right)} \cdot\left[\frac{1+K_{\mathrm{CaBL}}\left\{\mathrm{Ca}^{2+}\right\}+K_{\mathrm{MgBL}}\left\{\mathrm{Mg}^{2+}\right\}+K_{\mathrm{NaBL}}\left\{\mathrm{Na}^{+}\right\}+K_{\mathrm{HBL}}\left\{H^{+}\right\}}{K_{\mathrm{CuBL}}+K_{\mathrm{CuOHBL}}\left\{\mathrm{OH}^{-}\right\}+K_{\mathrm{CuCO}_{3} \mathrm{BL}} K_{\mathrm{CuCO}_{3}}\left\{\mathrm{CO}_{3}^{2-}\right\}}\right]$

Time-dependent fraction of the total number of $\mathrm{Cu}$ binding sites occupied by $\mathrm{Cu}$ at $50 \%$ effect

$f_{\mathrm{CuBL}}^{50 \%}\left(t_{R}\right)=0.187+0.693 \exp \left(-t_{R} / 34.3\right), r^{2}=0.998$

Time-varying Hill coefficient function in valve closure response

$n\left(t_{R}\right)=1.221+0.998 \exp \left(-t_{R} / 37.7\right), r^{2}=0.891$,

Valve daily rhythm dynamic model ${ }^{\mathrm{a}}$

$\phi\left(t, C u^{2+}\right)=\phi(t, 0)+[1-\phi(t, 0)] \cdot R\left(t_{R}, C u^{2+}\right)$

Where

Fitted valve daily closing rhythm exposed to uncontaminated environment ${ }^{\mathrm{b}}$

$\phi(t, 0)= \begin{cases}\phi_{1}(t, 0)=12.3 \exp \left[-0.5\left(\frac{\ln \left(\frac{t}{4}\right)}{0.2}\right)^{2}\right]+3.8, & 0 \leq t \leq 7, r^{2}=0.84 \\ \phi_{2}(t, 0)=14.8 \exp \left[-0.5\left(\frac{\ln \left(\frac{t}{18.2}\right)}{0.083}\right)^{2}\right]+3.6, & 7<t \leq 24, r^{2}=0.92\end{cases}$

${ }^{a}$ Adopted from Liao et al. (2007)

${ }^{\mathrm{b}}$ Adopted from Liao et al. (2005)

The calculated formulas of metal ionic strength in a solution is (Snoeyink and Jenkins 1980)

$I=\frac{1}{2} \sum_{i=1}^{n} C_{i} \cdot Z_{i}^{2}$,

where $I$ is the total metal ionic strength $(\mathrm{M}), C$ is the analytic concentration (M) of each metal, and $Z$ is the valence charge number of each metal in a solution. Activity factor $(\gamma)$ of each metal can be calculated using Debye-Huckel limit law (Snoeyink and Jenkins 1980),

$$
\begin{aligned}
& \log r=-A \cdot Z^{2} \cdot \sqrt{I} \text { if } I<0.005 \mathrm{M}, \\
& A=1.82 \times 10^{6}(D T)^{-\frac{2}{3}},
\end{aligned}
$$

where $D$ is permittivity of water (78.3) and $T$ is solution temperature $\left({ }^{\circ} \mathrm{K}\right)$.

The calculated ionic activities (e.g., $\left\{\mathrm{Ca}^{2+}\right\}$, $\left\{\mathrm{Mg}^{2+}\right\},\left\{\mathrm{Na}^{+}\right\},\left\{\mathrm{H}^{+}\right\},\left\{\mathrm{OH}^{-}\right\}$and $\left.\left\{\mathrm{CO}_{3}^{2-}\right\}\right)$ were incorporated into a computational mechanism of $\operatorname{EC}_{50} 0_{\mathrm{CuBL}}\left(t_{R}\right)$ (Table 1, Eq. (T2)) associated with the fitted time-dependent fraction function $f_{\mathrm{CuBL}}^{50 \%}\left(t_{R}\right) \cdot f_{\mathrm{CuBL}}^{50 \%}\left(t_{R}\right)$ (Table 1 , Eq. (T3)) can be obtained from an experimental study of $\operatorname{EC} 50\left(t_{R}\right)$ data adopted from Tran et al. (2004). The stability constants for the binding of these cations to the BL (e.g., $K_{\mathrm{CuBL}}, K_{\mathrm{CaBL}}, K_{\mathrm{MgBL}}, K_{\mathrm{NaBL}}, K_{\mathrm{HBL}}$, $\left.K_{\mathrm{CuOHBL}}, K_{\mathrm{CuCO} 3}\right)$ to evaluate the site-specific time-dependent EC50 values (Table 1, Eq. (T2)) can be obtained from Liao et al. (2007).

The estimated activity factors of $\left[\mathrm{Cu}^{2+}\right]$ under various solution temperature and $\mathrm{pH}$ can be excellently fitted to acquire the optimal statistical model as $f($ Temp, $p H)$. By employing this fitted function of $\left[\mathrm{Cu}^{2+}\right]$ activity factor, a free $\mathrm{Cu}^{2+}$ activity can be computed to quantify its toxic effect on valve closure behavioral response. By implementing Cu-BLM-Corbicula model (Table 1, 
Eq. (T1)), we incorporated three calculating mechanisms of the site-specific time-dependent EC50 values (Table 1, Eq. (T2)), free $\mathrm{Cu}^{2+}$ activities and BLM-based time-varying Hill coefficient function $n\left(t_{R}\right)$ (Table 1, Eq. (T4)) into this computational mechanism of valve closing responsive proportion. We obtain the fitted function $n\left(t_{R}\right)$ from Liao et al. (2007).

A describable and dynamic visual mechanism $\left(\phi\left(t, C u^{2+}\right)\right)$ (Table 1, Eq. (T5)) in the variation of valve daily rhythm exposed to temperature/pHspecific $\mathrm{Cu}$ ion activities can then be constructed. This can be achieved by integrating the fitted valve daily closing rhythm function $\phi(t, 0)$ (Table 1 , Eq. (T6)) with the BLM-based dynamic clam responsive mechanism.

$\mathrm{Cu}-\mathrm{BLM}$-Corbicula model-based dynamic detection mechanism

A proportion-based observed fashion based on the valvometry conversion technique and auxiliary water quality sensors (e.g., temperature, $\mathrm{pH}$ and metal ionic concentration etc.) were used to carefully perform and evaluate the monitoring of time-varying closure rhythm of bivalves in field. Using the inverse operation derived from Eq. (T5) (Table 1), the expression $R\left(t_{R}, C u^{2+}\right)$ can be obtained as

$$
R\left(t_{R}, C u^{2+}\right)=\frac{\phi\left(t, C u^{2+}\right)-\phi(t, 0)}{1-\phi(t, 0)},
$$

where $\phi\left(t, \mathrm{Cu}^{2+}\right)$ is the observed dynamic variation of valve rhythm closure behavior exposed to waterborne $\mathrm{Cu}$ and $\phi(t, 0)$ is used as the built-in database.

The time-varying expression of waterborne free $\mathrm{Cu}^{2+}$-activity $\left\{\mathrm{Cu}^{2+}\right\}$ can be derived by inverse function of $R\left(t_{R}, C u^{2+}\right)$ as follows (Jou and Liao 2006),

$$
\left\{C u^{2+}\left(t_{R}\right)\right\}=\frac{\mathrm{EC} 0_{\mathrm{CuBL}}\left(t_{R}\right)}{\sqrt[n\left(t_{R}\right)]{\frac{1-R\left(t_{R}, C u^{2+}\right)}{R\left(t_{R}, C u^{2+}\right)}}} .
$$

By incorporating the advanced computational mechanism of $\operatorname{EC50} \mathrm{CuBL}\left(t_{R}\right)$, and the coded data of $n\left(t_{R}\right)$ (Table 1 , Eq. (T4)) built in program with the indirect observed clam closure response profile $\left(R\left(t_{R}, C u^{2+}\right)\right)$, the waterborne free $\mathrm{Cu}^{2+}$ activity $\left\{\mathrm{Cu}^{2+}\right\}$ can be inversely estimated as a indirect determinant value detected by a group of $C$. fluminea-based biosensors. In accordance with the calculating formula of $\left[\mathrm{Cu}^{2+}\right]$ activity factor, a temperature/pH-specific waterborne $\mathrm{Cu}$ ionic concentration $\left[\mathrm{Cu}^{2+}\right]$ can be evaluated by the present proposed detection system.

\section{Clam-based biological early warning system}

Based on Cu-BLM-Corbicula model, the fitted time-dependent metal-specific function which can represent effect concentrations of $\mathrm{Cu}$ causing $X \%$

Fig. 1 A constructed monitoring interface for practical simulation diagramming the function of a system testing with respect to the clam closure rhythm in response to site-specific time-dependent waterborne $\mathrm{Cu}$ concentration associated with other field measured water quality data in Hualien clam farm. The monitoring windows reveal eight panels: a input essential data and information including the ratio of simulation time (Actual time: Simulation time $=1 \mathrm{~s}: 1 \mathrm{~ms})$, the occurrence time of transitional center in curve $(1 \mathrm{~h})$, various time constant settings (Time constant: $3 \mathrm{~h}$ ), the present and accumulative response times (Present hour: minute and Accumulative hour: minute), a peak concentration of waterborne $\mathrm{Cu}$ assigning $\left(100 \mu \mathrm{g} \mathrm{L}^{-1}\right)$ and other field observation of water parameters (see text for detail descriptions), b the built-in profile of time-varying function of $n\left(t_{R}\right)$ for $\mathrm{Cu}^{2+}$ activity and time-dependent bivalve physiological parameter $f_{\mathrm{CuBL}}^{50 \%}\left(t_{R}\right)$, c the profile of input time-varying function of waterborne $\mathrm{Cu}$ concentration $\left(\mathrm{Cu}\left(t, t_{R}\right)=4 \times\right.$ $100 \exp (-((t-9)-1) / 3)[1-\exp (-((t-9)-1) / 3)] u(t-9)$, $\left.t_{R}=t-9\right)$, $\mathbf{d}$ the according $\mathrm{Cu}^{2+}$ activity profile of timevarying function of site-specific waterborne $\mathrm{Cu}$, e the $\mathrm{Cu}^{2+}$ activity profile of time-varying function of site-specific EC50 $\mathrm{CuBL}\left(t_{R}\right)$, f the according dissolved $\mathrm{Cu}$ profile of time-varying concentration of site-specific $\operatorname{EC50} \mathrm{CuBL}\left(t_{R}\right)$, g the dose-response profile of the Cu-BLM-Corbicula model-based function $R\left(t_{R}, C u^{2+}\right)$ at any integration time $t_{R}$, and $\mathbf{h}$ the variation of bivalve circadian closing rhythm in response to site-specific waterborne $\mathrm{Cu}$ at any given time $t$ 

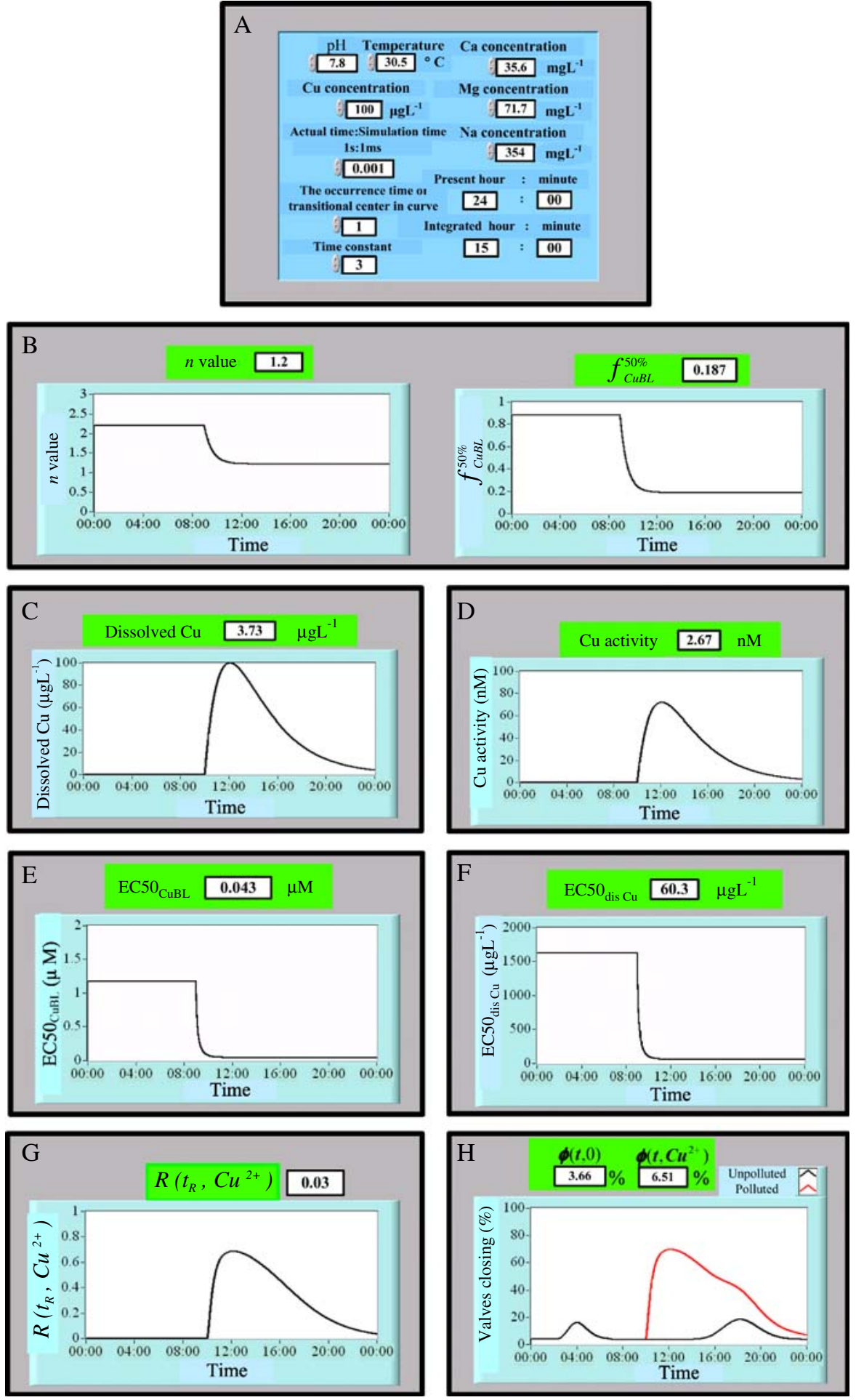
of total valve closure response of clam at different response times can be represented as,

$\operatorname{ECX}_{\mathrm{CuBL}}\left(t_{R}\right)=\frac{f_{\mathrm{CuBL}}^{X \%}\left(t_{R}\right)}{1-f_{\mathrm{CuBL}}^{X \%}\left(t_{R}\right)} \cdot\left[\frac{1+K_{\mathrm{CaBL}}\left\{C a^{2+}\right\}+K_{\mathrm{MgBL}}\left\{M g^{2+}\right\}+K_{\mathrm{NaBL}}\left\{N a^{+}\right\}+K_{\mathrm{HBL}}\left\{H^{+}\right\}}{K_{\mathrm{CuBL}}+K_{\mathrm{CuOHBL}}\left\{O H^{-}\right\}+K_{\mathrm{CuCO}_{3} \mathrm{BL}} K_{\mathrm{CuCO}_{3}}\left\{C O_{3}^{2-}\right\}}\right]$,

where $\operatorname{ECX}_{\mathrm{CuBL}}\left(t_{R}\right)$ is the time-dependent BLMpredicted acute $\mathrm{Cu}$ ECX value $(\mathrm{M})$ and $f_{\mathrm{CuBL}}^{X \%}\left(t_{R}\right)$ is the time-dependent fraction of the total number of $\mathrm{Cu}$ binding sites occupied by $\mathrm{Cu}$ at $\mathrm{X} \%$ effect.

To interpret the constructed computational mechanism of a proposed site-specific BLM-based early warning $\mathrm{Cu}$ concentration, the published $\mathrm{EC} 20\left(t_{R}\right), \mathrm{EC} 50\left(t_{R}\right)$ and $\mathrm{EC} 80\left(t_{R}\right)$ profiles based on Tran et al. (2004) were adopted to calculate the corresponding waterborne $\mathrm{Cu}$ ionic activity, i.e., $\mathrm{EC} 20_{\mathrm{CuBL}}\left(t_{R}\right), \mathrm{EC}_{50} \mathrm{CuBL}\left(t_{R}\right)$ and $\mathrm{EC} 80_{\mathrm{CuBL}}\left(t_{R}\right)$. Then, the time-dependent fraction of the total number of $\mathrm{Cu}$ binding sites occupied by $\mathrm{Cu}$ at $20 \%, 50 \%$ and $80 \%$ effect $\left(f_{\mathrm{CuBL}}^{20 \%}\left(t_{R}\right), f_{\mathrm{CuBL}}^{50 \%}\left(t_{R}\right)\right.$ and $\left.f_{\mathrm{CuBL}}^{80 \%}\left(t_{R}\right)\right)$ were estimated, respectively. We fitted the estimated $f_{\mathrm{CuBL}}^{20 \%}\left(t_{R}\right), f_{\mathrm{CuBL}}^{50 \%}\left(t_{R}\right)$ and $f_{\mathrm{CuBL}}^{80 \%}\left(t_{R}\right)$ values at different integrated response times of $10,15,30,60,120$, and 300 min to obtain a two-variable optimal mathematical formula of $f_{\mathrm{CuBL}}^{X \%}\left(X, t_{R}\right)$.

First, a $X$ value was logged in to compute the time-varying fraction of the total number of $\mathrm{Cu}$ binding sites occupied by $\mathrm{Cu}$ at $X \%$ effect in a human-machine interface window. We integrated the advanced computational mechanism associated with the stability constants (e.g., $K_{\mathrm{CuBL}}$, $\left.K_{\mathrm{CaBL}}, K_{\mathrm{MgBL}}, K_{\mathrm{NaBL}}, K_{\mathrm{HBL}}, K_{\mathrm{CuOHBL}}, K_{\mathrm{CuCO} 3}\right)$, the calculated ionic activities (e.g., $\left\{\mathrm{Ca}^{2+}\right\},\left\{\mathrm{Mg}^{2+}\right\}$, $\left\{\mathrm{Na}^{+}\right\},\left\{\mathrm{H}^{+}\right\},\left\{\mathrm{OH}^{-}\right\}$and $\left.\left\{\mathrm{CO}_{3}^{2-}\right\}\right)$, and the coded formula $f_{\mathrm{CuBL}}^{X \%}\left(X, t_{R}\right)$ into a computational mechanism of $\mathrm{ECX}_{\mathrm{CuBL}}\left(t_{R}\right)$. Then the computed time-varying $\mathrm{Cu}^{2+}$-activity causing $X \%$ effect $\left(\operatorname{ECX}_{\mathrm{CuBL}}\left(t_{R}\right)\right)$ was adopted as a threshold value to compare the waterborne dynamic free $\mathrm{Cu}^{2+}$ activity $\left\{C u^{2+}\left(t_{R}\right)\right\}$ estimated from the advanced computational mechanism detected by a group of C. fluminea-based biosensors. When the estimated $\left\{\mathrm{Cu}^{2+}\left(t_{R}\right)\right\}$ value exceeds the site-specific threshold $\operatorname{ECX}_{\mathrm{CuBL}}\left(t_{R}\right)$ value that sustains a given response time (e.g., $10 \mathrm{~min}$ ), and then the alarm is triggered.
To evaluate the sensitivity of such a $C$. flumineabased BEWS, a computational mechanism of a site-specific BLM-based early warning $\mathrm{Cu}$ concentration set by an operator was adopted to estimate a $\mathrm{Cu}$-induced threshold concentration. For obtaining a rapid and reliable response to such a C. fluminea-based BEWS, the operator can select the initial $\operatorname{ECX}_{\mathrm{CuBL}}\left(t_{R}\right)$ value multiplied by the decay value of one or two time constant in an exponential function (i.e., $e^{-1} \cdot \operatorname{ECX}_{\mathrm{CuBL}}\left(t_{R}=0\right)$ or $\left.e^{-2} \cdot \operatorname{ECX}_{\mathrm{CuBL}}\left(t_{R}=0\right)\right)$ as a responsive threshold value (referred to as an operational breakdown point) in that the according dynamic response time in various aquatic environments can be determined.

Data analysis and synthesis/simulation scheme

A Windemere Humic Aqueous Model (WHAM) Version 6 (WHAM VI, Centre for Ecology \& Hydrology, Lancaster, UK) was used to perform the calculation of equilibrium chemical species. We used TableCurve 3D (Version 4.0, AISN Software Inc., Mapleton, OR, USA) to perform all the statistics. The virtual instrumental technology developed from the LabVIEW graphic control program language (Version 7.0, NI Inc., North Mopac Expressway, Austin, USA) in a personal computer was used to implement the $C$. flumineabased dynamic metal detection mechanism to develop an integrated biomonitoring system for online in situ monitoring waterborne $\mathrm{Cu}$.

\section{Results}

Practical simulation windows

To demonstrate the performance of the proposed dynamic clam-based synthesis process, we systematically construct LabVIEW-based monitoring 

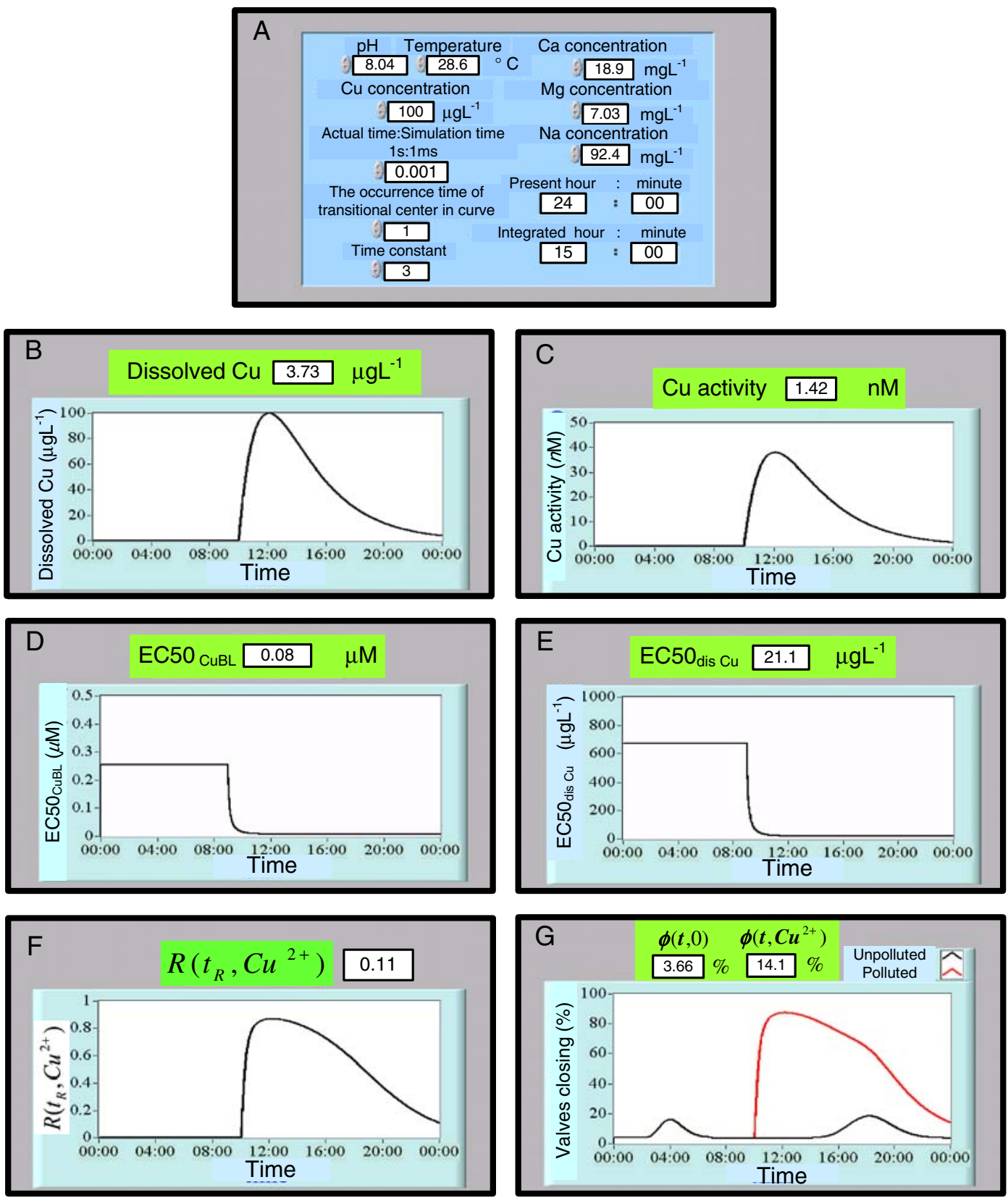

Fig. 2 Outcome of the system testing for practical simulation in a chosen clam farm sited at Changhua revealing seven monitoring interfaces: a input essential parameters such as the time lag of pollution, a peak concentration of waterborne $\mathrm{Cu}$ associated with other field observation of water parameters, were keyed into the data/information panel, b the input time-varying functions of waterborne $\mathrm{Cu}$ concentration were assumed as the same expression (Fig. 1c), $\mathbf{c}$ the according $\left\{\mathrm{Cu}^{2+}\right\}$ profile of time-varying

function of site-specific waterborne $\mathrm{Cu}, \mathbf{d}$ the $\left\{\mathrm{Cu}^{2+}\right\}$ profile of time-varying function of site-specific $\operatorname{EC50} \mathrm{CuBL}\left(t_{R}\right)$, e the according dissolved $\mathrm{Cu}$ profile of time-varying concentration of site-specific EC50 $0_{\mathrm{CuBL}}\left(t_{R}\right)$, $\mathbf{f}$ the dose-timeresponse profile of the Cu-BLM-Corbicula model-based function $R\left(t_{R}, C u^{2+}\right)$, and $\mathbf{g}$ the circadian rhythm variation of valve closing in response to site-specific waterborne $\mathrm{Cu}$ at any given time $t$ 
Fig. 3 Response surface showing the computed $f_{\mathrm{CuBL}}^{20 \%}, f_{\mathrm{CuBL}}^{50 \%}$ and $f_{\mathrm{CuBL}}^{80 \%}$ values at different integrated response times to be fitted to obtain a two-variable optimal response surface function

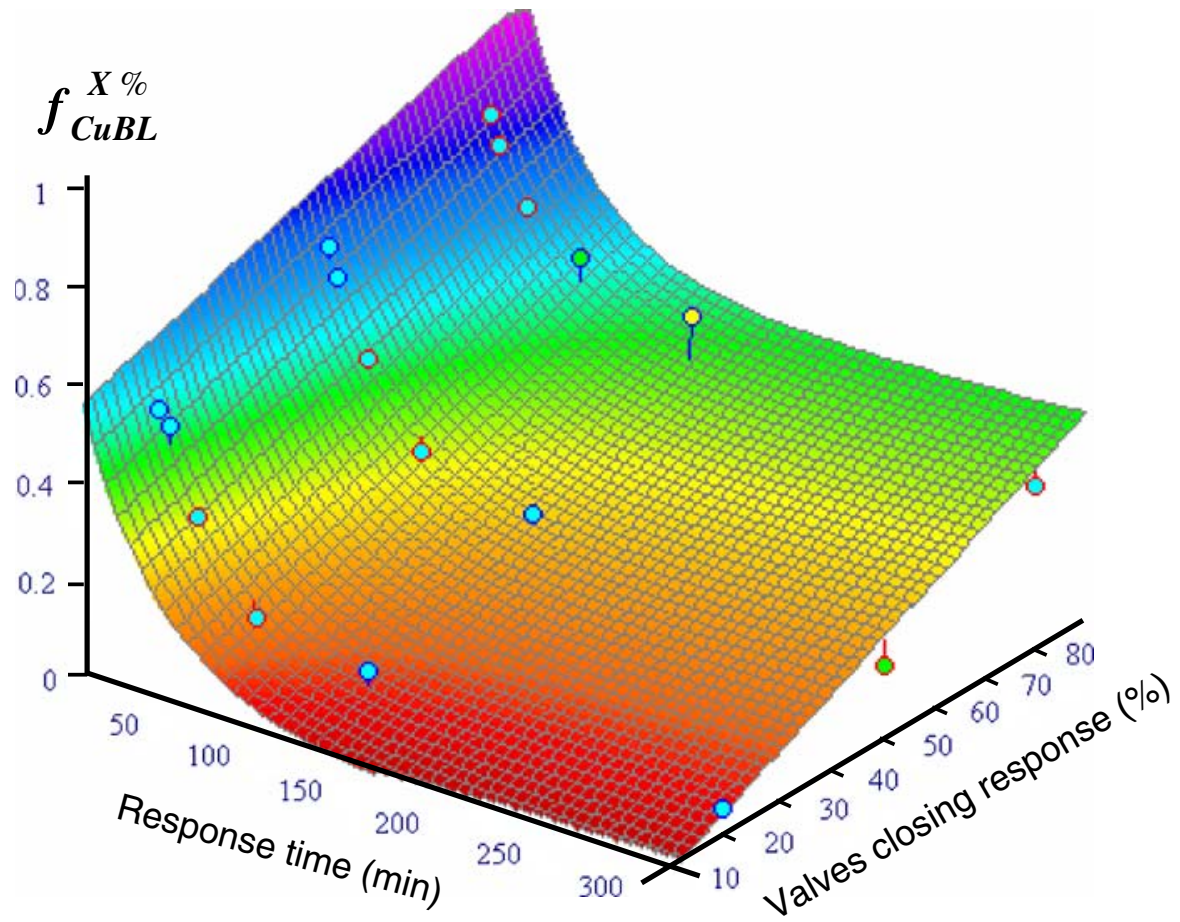

windows to explicitly illustrate the site-specific bivalve closure rhythm responses in two selected clam farms located at Hualien (Fig. 1) and Changhua (Fig. 2), respectively.

The basic input data and display information in monitor 1 (Fig. 1a) include the ratio of actual and simulation times, the time lag of pollution, the present and accumulative response times, a simulated time-varying concentration of waterborne $\mathrm{Cu}$ associated with other field observation of water parameters such as $\mathrm{pH}$, temperature, hardness (expressed as $\mathrm{Ca}$ and $\mathrm{Mg}$ ), other dissolved metal (e.g., $\mathrm{Na}, \mathrm{Fe}$ and $\mathrm{Zn}$ ) and inorganic complexation concentration (e.g., $\mathrm{Cl}^{-}$and $\mathrm{SO}_{4}^{2-}$ ). Both monitors 2 and 3 (Fig. 1b) are built-in data based on the computational mechanism of Eqs. (T3) $\left(f_{\mathrm{CuBL}}^{50 \%}\left(t_{R}\right)\right)$ and (T4) $\left(n\left(t_{R}\right)\right)$ in Table 1.

The display monitor 4 (Fig. 1c) shows the assumed time-varying function of waterborne $\mathrm{Cu}$ concentration. The calculating principles of metal ionic strength and activity factors (Eqs. 1-3) were incorporated into the coded computational
Fig. 4 Bivalve monitoring display windows showing performance and simulation results of a $C$. fluminea-based BEWS in Hualien clam farms at water temperature $30.5^{\circ} \mathrm{C}$ with pH 7.8 (panels: e-g) and $20^{\circ} \mathrm{C}$ with $\mathrm{pH} 6.0$ (panels: h-l), respectively. a the simulation (field observation) of valve movement associated with valvometric conversion technique, b a probabilistic model-based rhythm at valve closing in a group of $C$. fluminea exposed to waterborne $\mathrm{Cu}$, c the estimation of time-varying valve closing response profile based on the Cu-BLM-Corbicula model, d two parameters $\left(f_{\mathrm{CuBL}}^{50 \%}\left(t_{R}\right)\right.$ and $\left.f_{\mathrm{CuBL}}^{10 \%}\left(t_{R}\right)\right)$ built in the compiled database in the LabVIEW program, e the site-specific activity of waterborne $\mathrm{Cu}$ and $\mathrm{EC} 10_{\mathrm{CuBL}}\left(t_{R}\right)$ alarm-threshold, $\mathbf{f}$ the site-specific concentration of waterborne $\mathrm{Cu}$ and $\mathrm{EC} 10_{\text {dis } \mathrm{Cu}}\left(t_{R}\right)$ alarm-threshold, $\mathrm{g}$ the panel of displaying dynamic response time and sitespecific threshold concentration under setting EC10 and EC50 alarm conditions, $\mathbf{h}$ the $\mathrm{Cu}^{2+}$ activity profile of time-varying function of site-specific $\operatorname{EC} 50_{\mathrm{CuBL}}\left(t_{R}\right), \mathbf{i}$ the according dissolved $\mathrm{Cu}$ profile of time-varying concentration of site-specific $\mathrm{EC} 50_{\mathrm{dis}} \mathrm{Cu}\left(t_{R}\right), \mathbf{j}$ the activity variation of site-specific waterborne $\mathrm{Cu}$ and $\mathrm{EC10} \mathrm{CuBL}_{\mathrm{L}}\left(t_{R}\right)$ alarmthreshold, $\mathbf{k}$ the concentration variation of the site-specific waterborne $\mathrm{Cu}$ and $\mathrm{EC} 10_{\text {dis } \mathrm{Cu}}\left(t_{R}\right)$ alarm-threshold, and $\mathbf{l}$ the panel showing dynamic response time and site-specific threshold concentration under EC10 and EC50 alarmsetting conditions 

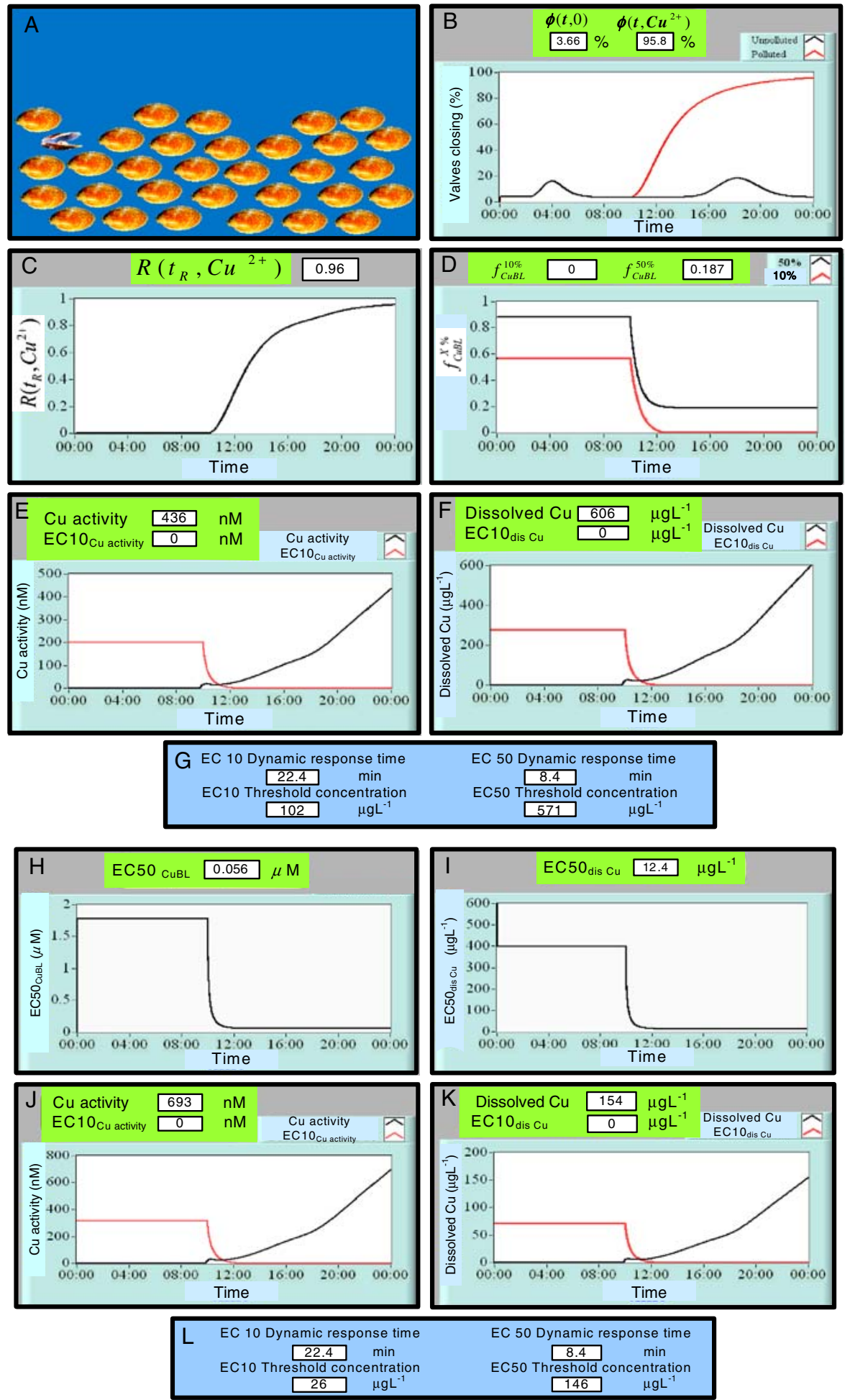
mechanism to obtain the estimation of site-specific waterborne ionic activities.

To estimate activity factor of $\left[\mathrm{Cu}^{2+}\right]$, the fitted form $f($ Temp, $p H)$ can be modeled as a twovariable with three-parameter linear regression,

$$
\begin{aligned}
\gamma_{C u}= & -0.0031422 \times \text { Temp }-0.114652 \\
& \times p H+1.03582\left(r^{2}=0.94\right) .
\end{aligned}
$$

The simulated time-varying profile of site-specific waterborne $\mathrm{Cu}$ activity can be accordingly obtained (monitor 5 in Fig. 1d). To evaluate the site-specific time-dependent $\mathrm{EC} 50_{\mathrm{CuBL}}$ value, the combination of Eqs. (T2) and (T3) is compiled into the computational mechanism. Therefore, the time-varying function of EC50 $\mathrm{CuBL}$ and $\mathrm{EC} 50_{\mathrm{dis}} \mathrm{Cu}$ were shown in the display monitors 6 and 7 , respectively (Fig. 1e and f). The display monitor 8 (Fig. 1g) shows the Cu-BLM-Corbicula modelbased dose-time-response profile $\left(R\left(t_{R}, C u^{2+}\right)\right)$.

The display monitor 9 (Fig. $1 \mathrm{~h}$ ) shows the variation of valve daily closure rhythm exposed to sitespecific waterborne $\mathrm{Cu}$ ionic activity at any given time $t$ (i.e. $\phi\left(t, C u^{2+}\right)$ ), indicating the proportion statuses of valve closing exposed to polluted and unpolluted environment, respectively.

The predicted $30 \mathrm{~min}$ and $120 \mathrm{~min}-\mathrm{EC} 50 \mathrm{~s}(84.1$ and $23.7 \mu \mathrm{g} \mathrm{L}^{-1}$ ) in Changhua clam farms (Fig. 2e) is lower than those (190.4 and $\left.55.6 \mu \mathrm{g} \mathrm{L}^{-1}\right)$ in Hualien (Fig. 1f) under the same input timevarying waterborne $\mathrm{Cu}$ concentration (Figs. 1c and $2 b$ ). The results reveal that the dose-response profile in Changhua clam farms (Fig. 2f) experienced the largest proportion of valve closure response in comparison with that in Hualien (Fig. 1g).

Simulation of biological early warning system

Given the calculated $\operatorname{EC} 20_{\mathrm{CuBL}}\left(t_{R}\right), \operatorname{EC} 50_{\mathrm{CuBL}}\left(t_{R}\right)$ and $\mathrm{EC} 80_{\mathrm{CuBL}}\left(t_{R}\right)$ profile associated with known ionic compositions and $\log K$ estimates, the timedependent $f_{\mathrm{CuBL}}^{20 \%}, f_{\mathrm{CuBL}}^{50 \%}$ and $f_{\mathrm{CuBL}}^{80 \%}$ values at different response times of 10, 15, 30, 60, 120, and $300 \mathrm{~min}$ could be estimated by fitting Eq. 6 . A two-variable response surface function is best fit the $f_{\mathrm{CuBL}}^{20 \%}\left(t_{R}\right), f_{\mathrm{CuBL}}^{50 \%}\left(t_{R}\right)$ and $f_{\mathrm{CuBL}}^{80 \%}\left(t_{R}\right)$ values (Fig. 3),

$$
\begin{aligned}
f_{\mathrm{CuBL}}^{X \%}\left(X, t_{R}\right)= & -0.1975+(0.00773 \cdot X) \\
& +0.693 \cdot \exp \left(-\frac{t_{R}}{a}\right),
\end{aligned}
$$

with $a=34.3$ (95\% CI: 25.58-48.31) $\left(r^{2}=0.98\right)$. When $X$ equals $10, f_{\mathrm{CuBL}}^{10 \%}\left(t_{R}\right)$ has the form as,

$$
f_{\mathrm{CuBL}}^{10 \%}\left(t_{R}\right)=-0.12+0.693 \cdot \exp \left(-\frac{t_{R}}{34.3}\right) .
$$

By substituting Eq. 9 into Eq. 6, we obtain the BLM-based EC10 function

$$
\begin{aligned}
\operatorname{EC} 10_{\mathrm{CuBL}}\left(t_{R}\right)= & \frac{-0.12+0.693 \cdot \exp \left(-\frac{t_{R}}{34.3}\right)}{1.12-0.693 \cdot \exp \left(-\frac{t_{R}}{34.3}\right)} \\
& \cdot\left\{\frac{1+K_{\mathrm{CaBL}}\left\{C a^{2+}\right\}+K_{\mathrm{MgBL}}\left\{M g^{2+}\right\}+K_{\mathrm{NaBL}}\left\{N a^{+}\right\}+K_{\mathrm{HBL}}\left\{H^{+}\right\}}{K_{\mathrm{CuBL}}+K_{\mathrm{CuOHBL}} K_{\mathrm{CuOH}}\left\{O H^{-}\right\}+K_{\mathrm{CuCO}_{3} \mathrm{BL}} K_{\mathrm{CuCO}_{3}}\left\{C O_{3}^{2-}\right\}}\right\} .
\end{aligned}
$$

Equation 10 is used to predefine a site-specific waterborne $\mathrm{Cu}$ alarm-threshold concentration.

Figures 4 and 5 demonstrate the performance and simulation results of a dynamic clam synthesis under site-specific aquatic environmental conditions in Hualien and Changhua clam farms, respectively. A simulated daily rhythm in a group of $C$. fluminea exposed to waterborne $\mathrm{Cu}$ (Fig. 4a and b) was used as a field observation of the proportion of clam closure rhythm to obtain the estimation (Fig. 4c) of the valve closing response profile $R\left(t_{R}, C u^{2+}\right)$. Using the parameters $\left(n\left(t_{R}\right), f_{\mathrm{CuBL}}^{50 \%}\left(t_{R}\right)\right.$ and $\left.f_{\mathrm{CuBL}}^{10 \%}\left(t_{R}\right)\right)$ built in the compiled database (Figs. $1 \mathrm{~b}$ and $4 \mathrm{~d}$ ) and field observation of water parameters (Fig. 1a), the integrated computational mechanisms can be implemented. Thus based on $\mathrm{EC} 50_{\mathrm{CuBL}}\left(t_{R}\right)$ profile (Fig. 1e), associated with coded Eqs. 5, 7 and 10, 
Fig. 5 Simulation outcome representing the function of a system testing for a clam-based BEWS performed in Changhua clam farms at water temperature $28.6^{\circ} \mathrm{C}$ with $\mathrm{pH} 8.04$ (panels: a-e) and $20^{\circ} \mathrm{C}$ with $\mathrm{pH} 6.0$ (panels: $\mathbf{f}-\mathbf{j}$ ), respectively
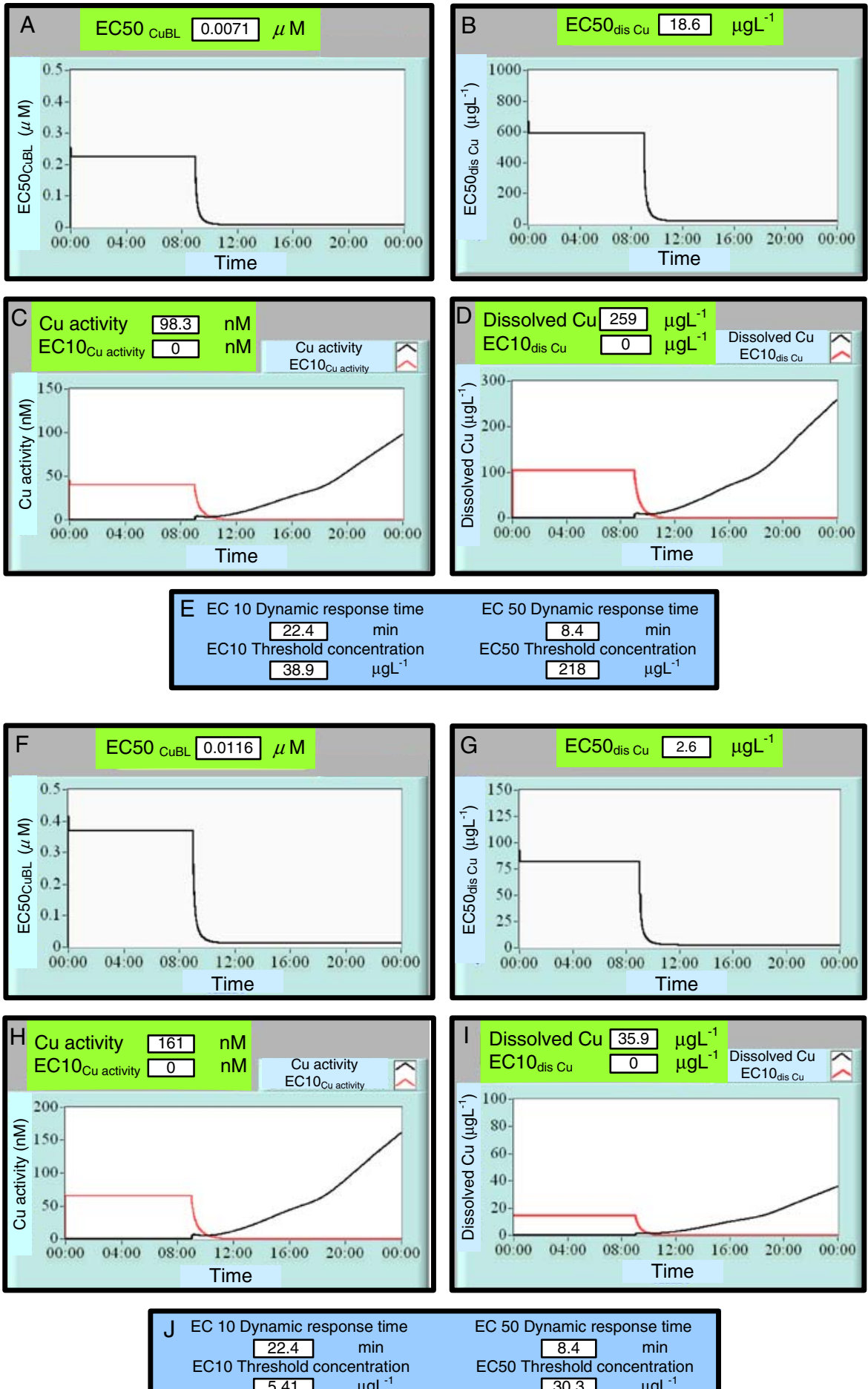

EC 50 Dynamic response time $\begin{array}{ccc} & 8.4 & \text { min } \\ \text { EC50 Threshold concentration }\end{array}$ $30.3 \mu \mathrm{gL}^{-1}$ the site-specific waterborne $\mathrm{Cu}$ and $\mathrm{EC} 10_{\mathrm{CuBL}}\left(t_{R}\right)$ alarm-threshold activity and concentration can be obtained, respectively (Figs. 4e and f).
Our results indicate that the sensitivity of such a C. flumina-based BEWS was dependent on a BLM-based early warning $\mathrm{Cu}$ concentration set 
Table 2 Comparison between the results shown in Figs. 4 and 5 illustrating the site-specific $\mathrm{Cu}$ alarm-triggering threshold value and occurrence time for a clam-based

\begin{tabular}{lllllll}
\hline Clam farm & $\mathrm{pH}$ & Temp $\left({ }^{\circ} \mathrm{C}\right)$ & $\begin{array}{l}\text { Occurrence time } \\
\text { of pollution }\end{array}$ & $\begin{array}{l}\text { Alarm-triggering } \\
\text { time }\end{array}$ & \multicolumn{2}{c}{\begin{tabular}{l} 
Site-specific Cu alarm trigger value \\
\cline { 3 - 6 } Concentration $\left(\mu \mathrm{L}^{-1}\right)$
\end{tabular}} \\
\hline Hualien & $7.80^{\mathrm{a}}$ & $30.5^{\mathrm{a}}$ & $10: 00$ & $11: 22$ & 23.8 & 18 \\
Changhua & $6.00^{\mathrm{b}}$ & $20.0^{\mathrm{b}}$ & $10: 00$ & $11: 15$ & 6.7 & 31 \\
& $8.04^{\mathrm{a}}$ & $28.6^{\mathrm{a}}$ & $09: 00$ & $10: 12$ & 11.4 & 4.4 \\
\hline
\end{tabular}

${ }^{\text {a}}$ Field measured value

${ }^{\mathrm{b}}$ Assumed value used in the model simulation

by an operator (Fig. 4g). From a comparison among the results shown in Figs. 4 and 5, the sitespecific $\mathrm{Cu}$ alarm-triggering threshold value and occurrence time can be obtained for a clam-based BEWS performed in Hualien and Changhua clam farms under various aquatic scenarios (Table 2). The result indicates that a real waterborne dissolved $\mathrm{Cu}$ strongly depends on temperature/ $\mathrm{pH}$-specific environmental conditions.

\section{Discussion}

System sensitivity and dynamic response time

Two different monitoring reactions related to the proportion of clam closure behavior can be appropriately selected as triggering thresholds: (1) the time response $\left(T_{X \%}\right)$ describing the speed of valve closure response to a nominal concentration, e.g., $T_{10 \%}$ corresponding to the time for $10 \%$ valve closing in bivalves exposed to a specific concentration and (2) the effective concentration (ECX) causing $X \%$ effect of total valve closure response of clam.

Tran et al. (2004) pointed out that the estimated response time-specific EC20 to EC80 values could obviously reflect the sensitivity thresholds. To obtain a better insight into the ability of a $C$. Aluminea-based dynamic $\mathrm{Cu}$ detection mechanism, the principles of hydrochemistry and bioavailability on biological response were integrated with BLM to modify the external effective concentration. On the other hand, response time can directly reflect the speed of response mechanism using bivalves as biosensor to detect waterborne $\mathrm{Cd} / \mathrm{Cu}$ (Tran et al.
BEWS performed in Hualien and Changhua clam farms under temperature/pH-specific environmental conditions
2003, 2004). Figure 6 shows the dissolved $\mathrm{Cu}$ profile of time-varying function of site-specific $\mathrm{EC} 10_{\text {dis } \mathrm{Cu}}\left(t_{R}\right)$ and $\mathrm{EC} 50_{\text {dis } \mathrm{Cu}}\left(t_{R}\right)$ for a selected clam farm in Hualien under temperature/pHspecific environmental conditions. Figure 6 also
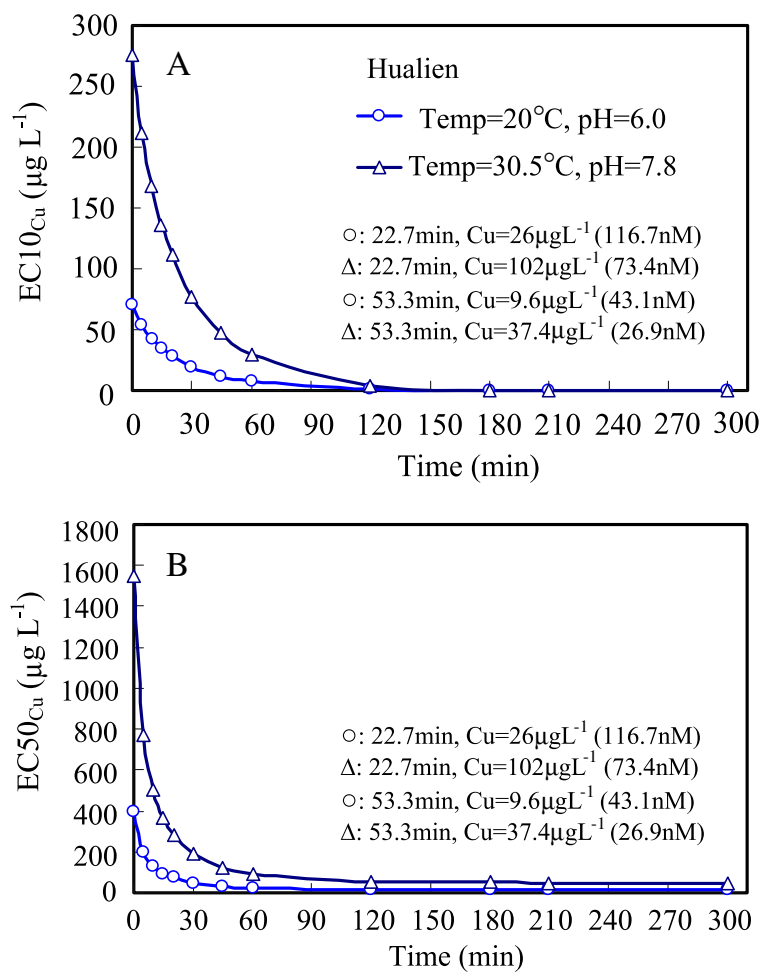

Fig. 6 Calculated dissolved $\mathrm{Cu}$ profile of site-specific a $\mathrm{EC} 10_{\mathrm{dis} \mathrm{Cu}}\left(t_{R}\right)$ and $\mathbf{b} \mathrm{EC} 50_{\text {dis } \mathrm{Cu}}\left(t_{R}\right)$ under temperature-specific and $\mathrm{pH}$-specific conditions for reacting the sensitivity thresholds of a clam-based BEWS performed in Hualien clam farm 
illustrates how the system sensitivity threshold can be used to detect waterborne $\mathrm{Cu}$ associated with exposure time in Hualien clam farm.

In the same aquatic scenario, indeed, relatively higher $\mathrm{Cu}$ concentrations can provoke quicker responses and lower $\mathrm{Cu}$ concentrations require longer exposure periods to be detected. Figure $6 \mathrm{a}$ shows that detection limitation of time response ( $T_{10 \%}$ ) of a dynamic clam synthesis is nearly $2 \mathrm{~h}$ and the detected threshold concentration of dissolved $\mathrm{Cu}$ is estimated to be $>3.6 \mu \mathrm{g} \mathrm{L}{ }^{-1}$ within 120 min after $\mathrm{Cu}$ occurred. In the present study, it hopes that the potential and limitations of such a clam-based BEWS can enable us to obtain clear understanding to precisely detect acute waterborne $\mathrm{Cu}$ changes.

Figure $6 \mathrm{~b}$ reveals that the detection limitation of a dynamic clam synthesis performed in Hualien clam farm is higher than $48.5 \mu \mathrm{g} \mathrm{L}^{-1}$ (at $30.5^{\circ} \mathrm{C}$ and $\mathrm{pH}=7.8$ ) and $12.4 \mu \mathrm{g} \mathrm{L}^{-1}$ (at $20.0^{\circ} \mathrm{C}$ and $\mathrm{pH}=6.0$ ) within $5 \mathrm{~h}$, depending on the site-specific environmental conditions. Tran et al. (2004) indicated that $\mathrm{Cu}$ concentrations of more than $4 \mu \mathrm{g} \mathrm{L} \mathrm{L}^{-1}$ (95\% CI: 2.3-8.8 $\mu \mathrm{g} \mathrm{L}^{-1}$ ) could be determined within 300 min after $\mathrm{Cu}$ occasional addition and lower values could not be identified from background concentrations.

In order to take into account the reliability of response in such a BEWS, the operational breakdown point between time response and rapidity needs to be regulated. The operator can predefine a response time $\left(T_{X \%}\right)$ in compliance with an expected sensitivity threshold, distinguishing whether minimal detectable waterborne $\mathrm{Cu}$ raises in length of the exposure period or not. For example, Fig. 6b illustrates that the response time $T_{50 \%}$ of a dynamic clam synthesis performed in Hualien clam farm can be set within 8.8 and 28.1 min under temperature/pH-specific conditions. The result reveals that the detected thresholds of dissolved $\mathrm{Cu}$ were accordingly estimated to be higher than 145 (at $20.0^{\circ} \mathrm{C}$ and $\mathrm{pH}=6.0$ within $8.8 \mathrm{~min}$ ), 568 (at $30.5^{\circ} \mathrm{C}$ and $\mathrm{pH}=7.8$ within $8.8 \mathrm{~min}$ ), 53.5 (at $20.0^{\circ} \mathrm{C}$ and $\mathrm{pH}=6.0$ within $28.1 \mathrm{~min}$ ) and 209 (at $30.5^{\circ} \mathrm{C}$ and $\mathrm{pH}=7.8$ within $28.1 \mathrm{~min}$ ) $\mu \mathrm{g} \mathrm{L} \mathrm{L}^{-1}$.

Obviously, the two time-varying EC50 dis Cu profiles (Fig. 6b) were characterized by two "breakdown points" (28.1 min, 53.5 and $209 \mu \mathrm{g} \mathrm{L}^{-1}$ ), respectively. A rapid response occurring within
$<28.1$ min can be detected by $\mathrm{Cu}$ concentrations $>53.5$ and $209 \mu \mathrm{g} \mathrm{L}^{-1}$, respectively. In the detection of $\mathrm{Cu}$ concentrations of less than 53.5 and $209 \mu \mathrm{g} \mathrm{L} \mathrm{L}^{-1}$, a slower detection mechanism requires much longer response times. Therefore, the response mechanism with the low detection threshold was not triggered rapidly and the sufficient response times are necessary for some sensitivity thresholds (Fig. 6). By comparison with the $\mathrm{Cu}$ detection mechanism obtained by $C$. fluminea exposure experiment in the laboratory (Tran et al. 2004), the time-varying EC50 ${ }_{\text {dis }}$ Cu profiles reveal a breakdown point at $23 \mu \mathrm{g} \mathrm{L}^{-1}$ with a response time 28 min using the same calculating protocols.

\section{Surrogate response signal}

When bivalves filter waterborne plankton or organic matter for uptake, they extend siphons protruding at the posterior end from their bivalve shells to supply a continuous stream of water over the gills. Bivalves can filter a great quantity of water daily and accumulate pollutants in the tissues to a concentration of $10^{3}$ to $10^{4}$ times that of ambient water (Pynnonen 1990). Therefore, bivalve gaping behavior directly excites a great influence on both the efficiency of water filtration and the accumulation rate of pollutants. Information on the behavioral rhythm exhibited by bivalves is a potentially important tool for biomonitoring of water quality. Bivalves close their shell to enable themselves to isolate pollutant damage as a protective measure when exposed to contaminants. Thus the bivalve biological response ability to close its shell can be used as an alarm signal to monitor water quality in aquatic environments. In accordance with the present measuring valvometric technique, two different monitoring responses with respect to behavioral activities of the clam can be appropriately selected as triggering alarms: (1) closure (designated as C-alarm) and (2) filtration decreasing (designated as D-alarm).

When the bivalve closes its shells lower than the set percentage of valve position, a timer is triggered. If bivalve re-opens the shell to a level higher than the set percentage, the timer is reset. The C-alarm means that a given number of bivalves keep their closure state for a given number of minutes in that the alarm threshold is triggered. 
For bivalves exposed to toxicant, decreasing the average magnitude of shell gape (D-alarm) depends on the decreasing filtration activity and could reveal the present degree of pollution in the water. Thus, D-alarm is also an advantageous biological responsive endpoint as a setting alarm threshold of polluted aquatic environment.

On the other hand, changes in bivalve daily opening time observed by measuring valvometric technique can assist a dynamic clam synthesis to explicitly distinguish the cause in eliciting valve closure response as another auxiliary biological responsive endpoint to avoid the occurrence of false alarm. Thus, it is suggested that such a dynamic clam synthesis can be employed to test the bivalve biological response ability to close its shell as an alarm signal to reflect clam's health when exposed to waterborne $\mathrm{Cu}$. In this study, the results implicate that both the more sensitive level and reliable range alarm signal can be considered to reduce the probability of false alarm.

\section{System false-alarm rate}

For any pattern of BEWSs, false alarm is one important issue which needs to be especially treated in that the occurrence of false alarms are generally occurred by equipment malfunctions or changes in water quality conditions. For such a dynamic clam synthesis performed in any field, a further limitation with respect to the uncertainty/variability problem provoked by various environmental conditions (e.g., photoperiod, light intensity, DO and trophic additions) must be considered, which affect the bivalve behavioral rhythm response and further adjust the sensitivity of the signal when false responses occur (Higgins 1980; Englund and Heino 1994; Ortmann and Grieshaber 2003).

Obviously, the influences and complexities of the environment are a key problem and also have to be taken into consideration. Furthermore, the site-specific bivalve daily rhythm exposed to uncontaminated aquatic environments should be built in the database of a dynamic clam synthesis associated with auxiliary water quality sensors such as temperature, $\mathrm{pH}$, conductivity and dissolved oxygen. To precisely evaluate the cause of provoking abnormal response of valve movement and reliably provide minimal false alarm estimation to waterborne $\mathrm{Cu}$, we have to carefully process the field observation of time-varying closure daily rhythm of bivalves in using the present developed approach.

To decrease the announced probability of false alarm, more reliable range alarm signals (e.g., changes in a minimum threshold of bivalve daily opening time and a decrease in average valve position threshold reflecting the reduction of clam filtration activity) should be taken into account to synthetically distinguish either the occurrence of pollution or the false alarm from the background noise or other disturbances.

We confirm that this study provides a promising methodology to develop a novel online clam-based biomonitoring system based on a valvometric conversion combined with the virtual instrumentation technique for simulating and estimating the valve behavioral reaction exposed to site-specific waterborne $\mathrm{Cu}$. In the future work, we also confidently believe that such a biomonitoring system to detect other metal toxic effects (e.g. $\mathrm{Cd}, \mathrm{Hg}$ and $\mathrm{As}$ ) in aquatic ecosystems can be implemented and realized by performing the similar protocol and following the basic principles related to the sensitivity and dynamic response time of a biosensor to an automated measurable biological response.

\section{References}

Borcherding, J., \& Volpers, M. (1994). The "Dreissenamonitor"-first results on the application of this biological early warning system in the continuous monitoring of water quality. Water Science and Technology, 29, 199-201.

Byrne, R., Gnaiger, E., McMahon, R., \& Dietz, T. (1990). Behavioral and metabolic responses to emersion and subsequent reimmersion in the freshwater bivalve Corbicula fluminea. The Biological Bulletin, 178, 251-259. doi:10.2307/1541826.

Cherry, D. S., \& Soucek, D. J. (2006). Case study: Comparison of Asian clam (Corbicula fluminea) in situ testing 
to several nontarget test organism responses to biocidal dosing at a nuclear power plant. In J. L. Farris, J. H. Van Hassel (Eds.), Freshwater bivalve ecotoxicology (pp. 285-305). Roca Raton: CRC.

Curtis, T. M., Williamson, R., \& Depledge, M. H. (2000). Simultaneous, long-term monitoring of valve and cardiac activity in the blue mussel Mytilus edulis exposed to copper. Marine Biology (Berlin), 136, 837-846. doi:10.1007/s002270000297.

Dohery, F. G., \& Cherry, D. S. (1988). Tolerance of the Asiatic clam Corbicula-spp to lethal levels of toxic stressors-a review. Environmental Pollution, 51, 269-313. doi:10.1016/0269-7491(88)90167-4.

Doherty, F. G., Cherry, D. S., \& Cairns, J. Jr. (1987). Valve closure responses of the Asiatic clam $C$. fluminea exposed to cadmium and zinc. Hydrobiologia, 153, 159-167. doi:10.1007/BF00006647.

Englund, M. P. V., \& Heino, P. M. (1994). Valve movement of Anodonta anatina and Unio tumidus (Bivlvia, Unionidae) in a eutrophic lake. Annales Zoologici Fennici, 31, 257-262.

Fournier, E., Tran, D., Denison, F., Massabuau, J.-C., \& Garnier-Laplace, J. (2004). Valve closure response to uranium exposure for a freshwater bivalve (Corbicula fluminea): Quantification of the influence of $\mathrm{pH}$. Environmental Toxicology and Chemistry, 23, 1108-1114. doi:10.1897/02-604.

Heinonen, J., Penttinen, O. P., Holopainen, I. J., \& Kukkonen, J. V. K. (2003). Sublethal energetic responses by Pisidium amnicum (Bivalvia) exposed to pentachlorophenol at two temperatures. Environmental Toxicology and Chemistry, 22, 433-438. doi:10.1897/1551-5028(2003)022<0433:SERBPA > 2.0. $\mathrm{CO} ; 2$.

Higgins, P. J. J. (1980). Effects of food availability on the valve movement and feeding behaviour of juvenile Crassostrea virginica (Gmelin). I. Valve movement and periodic activity. Journal of Experimental Marine Biology and Ecology, 45, 229-244. doi:10.1016/ 0022-0981(80)90060-X.

Jou, L. J., \& Liao, C. M. (2006). A dynamic artificial clam (Corbicula fluminea) allows parsimony on-line measurement of waterborne metals. Environmental Pollution, 144, 172-183. doi:10.1016/j.envpol.2005.12.032.

Kadar, E., Salanki, J., Jugdaohsingh, R., Powell, J. J., McCrohan, C. R., \& White, K. N. (2001). Avoidance responses to aluminium in the freshwater bivalve Anodonta cygnea. Aquatic Toxicology (Amsterdam, Netherlands), 55, 137-148. doi:10.1016/ S0166-445X(01)00183-7.

Le Pennec, G., \& Le Pennec, M. (2001). Evaluation of the toxicity of chemical compounds using digestive acini of the bivalve mollusk Pecten maximus L. maintained alive in vitro. Aquatic Toxicology (Amsterdam, Netherlands), 53,1-7. doi:10.1016/S0166445X(00)00163-6.

Liao, C. M., Jou, L. J., \& Chen, B. C. (2005). Riskbased approach to appraise valve closure in the clam Corbicula fluminea in response to waterborne metals. Environmental Pollution, 135, 41-52. doi:10.1016/j.envpol.2004.10.015.

Liao, C. M., Jou, L. J., Lin, C. M., Chiang, K. C., Chou, B. Y. H., \& Yeh, C. H. (2007). Predicting acute copper toxicity to valve closure behavior in the freshwater clam Corbicula fluminea supports the biotic ligand model. Environmental Toxicology, 22, 295-307. doi:10.1002/tox.20263.

Lopez-Barea, J., \& Pueyo, C. (1998). Mutagen content and metabolic activation of promutagens by molluscs as biomarkers of marine pollution. Mutation Research, 399, 3-15. doi:10.1016/S0027-5107(97)00262-5.

Markich, S. J. (2003). Influence of body size and gender on valve movement responses of a freshwater bivalve to uranium. Environmental Toxicology, 18, 126-136. doi:10.1002/tox.10109.

Mitchelmore, C. L., \& Chipman, J. K. (1998). DNA strand breakage in aquatic organism and potential values of the comet assay in environmental monitoring. Mutation Research, 399, 135-147. doi:10.1016/S00275107(97)00252-2.

Narbonne, J. F., Djomo, J. E., Ribeira, F. V., \& Garrigues, P. (1999). Accumulation kinetics of polycyclic aromatic hydrocarbons adsorbed to sediment by the mollusk Corbicula fluminea. Ecotoxicology and Environmental Safety, 42, 1-8. doi:10.1006/eesa. 1998.1701.

Niyogi, S., \& Wood, C. M. (2004). Biotic ligand model, a flexible tool for developing site-specific water quality guidelines for metals. Environmental Science \& Technology, 38, 6177-6192. doi:10.1021/es0496524.

Ortmann, C., \& Grieshaber, M. K. (2003). Energy metabolism and valve closure behaviour in the Asian clam Corbicula fluminea. The Journal of Experimental Biology, 206, 4167-4178. doi:10.1242/jeb.00656.

Paquin, P. R., Gorsuch, J. W., Apte, S., Batley, G. E., Bowles, K. C., Campbell, P. G. C., et al. (2002). The biotic ligand model: A historical overview. Comparative Biochemistry and Physiology, 133(Part C), 3-35.

Pynnonen, K. (1990). Aluminium accumulation and distribution in the freshwater clams (Unionidae). Comparative Biochemistry and Physiology, 97(Part C), 111-117. doi:10.1016/0742-8413(90)90180-H.

Sluyts, H., Van Hoof, F., Cornet, A., \& Paulussen, J. (1996). A dynamic new alarm system for use in biological early warning systems. Environmental Toxicology and Chemistry, 15, 1317-1323. doi:10.1897/ 1551-5028(1996)015<1317:ADNASF $>2.3 . \mathrm{CO} ; 2$.

Snoeyink, V. L., \& Jenkins, D. (1980). Water chemistry. New York: Wiley.

Tran, D., Ciret, P., Ciutat, A., Durrieu, G., \& Massabuau, J. C. (2003). Estimation of potential and limits of bivalve closure response to detect contaminants: Application to cadmium. Environmental Toxicology and Chemistry, 22, 914-920. doi:10.1897/ 1551-5028(2003)022<0914:EOPALO > 2.0.CO;2. 
Tran, D., Fournier, E., Durrieu, G., \& Massabuau, J. C. (2004). Copper detection in the Asiatic clam Corbicula fluminea: Optimum valve closure response. Aquatic Toxicology (Amsterdam, Netherlands), 66, 333-343. doi:10.1016/j.aquatox.2004.01.006.

Tran, D., Fournier, E., Durrieu, G., \& Massabuau, J. C. (2007). Inorganic mercury detection by valve closure response in the freshwater clam Corbicula fluminea: Integration of time and water metal concentration changes. Environmental Toxicology and Chemistry, 26, 1545-1551. doi:10.1897/06-390R1.1.
Wildridge, P. J., Werner, R. G., Doherty, F. G., \& Neuhauser, E. F. (1998). Acute effects of potassium on filtration rates of adult zebra mussels, Dreissena polymorpha. Journal of Great Lakes Research, 24, 629-636.

Wilson, J. T., Pascoe, P. L., Parry, J. M., \& Dixon, D. R. (1998). Evaluation of comet assay as a method for the detection of DNA damage in cells of a marine invertebrate, Mytilus edulis L. (Mollusca, Pelecipoda). Mutation Research, 399, 87-95, doi:10. 1016/S0027-5107(97)00268-6. 